This is the version of the article accepted for publication in CounterText (Special Issue: Theologies of Reading), 7 (1). pp. 73-89 published by Edinburgh University Press

https://doi.org/10.3366/count.2021.0216

https://www.euppublishing.com/loi/count

Accepted version downloaded from SOAS Research Online: http://eprints.soas.ac.uk/34945

\title{
My Grandmother Drank the Qur'an: Liquid Readings and Permeable Bodies in Bosnia
}

\author{
Safet HadžiMuhamedović \\ (University of Cambridge)
}

\begin{abstract}
:
Starting with a curious childhood memory, the author considers the practices of imbibing - or otherwise transforming and internalising - sacred texts as modes of reading in their own right. At the heart of the argument is a call for a receptive apprehension of reading, open to worlds beyond substance dualism and the detachment of text and meaning residing therein. Kaleidoscopic autobiographical elements merge with and extend through a variety of transmutational, syncretic practices, such as the rituals of 'erasure' (e.g. kombe) across the African continent, or the magical inscriptions (zapisi) and the ritual of 'horror pouring' (salivanje strave) in Bosnia. Water appears as a particularly efficacious agent, flowing between humans and more-than-humans and connecting different bodies, religions, and forms of knowledge. Noticing that the recurring motif of such practices is healing, the author wonders if the drinking of text might be a remedy against the political ontology of inter-corporeal distance. A radically intimate engagement with text, it is suggested, requires the kind of trust that allows for permeability - an alwayspotential openness, a new sort of liquid critical reading.
\end{abstract}

Keywords: liquid, drinking, permeable, text, trust, reading, Bosnia, anthropology, syncretism.

CounterText 7.1 (2021): 73-89

DOI: $10.3366 /$ count. 2021.0216

(C) Edinburgh University Press

www.euppublishing.com/count 
Have you ever consumed a text? Not figuratively. Have you ever ripped a page from a book and devoured it? Or dipped it in a glass of milk and gulped down the inky liquid? Many of us may have nibbled on paper at some point, but we would not necessarily think of it as an act of reading. If we were to (literally) ingest a text so as to make its knowledge possible within ourselves, one entire conceptual constellation might wobble, if not also silently collapse. We would have to know that the object is the subject (subject as topic, and subject as, say, person), not its mere representation or setting. And, we would also need to trust the power of such a delectable subject-object. In the absence of trust, our relation to text would always be dependent on some form of critical removal from it (counter to text).

In this article, I want to briefly think about the Bosnian and wider practices of imbibing - as well as ingesting and inhaling - sacred texts such as the Qur'an, and then touch upon the value of water as a knowledge conductor before I move on to some potential repercussions of these issues for the theologies and anthropologies of reading. Through these cases, I am not simply concerned with different (cultural, religious, and so on) ways of reading, which would entail but distinct modalities of one practice. Rather, I suggest that a receptive apprehension of reading makes itself possible through an openness to acts beyond the conventional detachment of text from its meaning in (or as) the world. To put it differently, I am joining the call for the prerequisite liberation in the research on reading of both text and subject from the imprisonment of ontological binaries (subject-object, meaning-form, and mind-matter).

This call has been well elaborated in anthropology, particularly over the two decades since the publication of Thinking Through Things (Henare, Holbraad, and Wastell 2007). The volume was concerned with the methodological challenge of accepting things as meanings in themselves - or rather exploring the thing-concept-as a way to avoid reasserting the pernicious analytical authority of substance dualism where and when it is unwarranted. In the same volume, for example, Henare considered the nineteenth-century British-Mäori Treaty of Waitangi and other documents that for Mäori also constitute taonga - things that do not merely 'represent' but rather are ancestral power (Henare 2007: 56). Likewise, in Holbraad's (2007) contribution, the powder (aché) used in séances by Cuban diviners 
is power, not its signifier: "aché (the "concept") is literally constituted by the things to which it would otherwise be assumed simply to "apply" (Holbraad 2007: 206). To consider the Treaty of Waitangi or aché as texts might seem reductive at first, but that is only if we assume to know what text as such really is. If we open to the possibility of not knowing, then 'text' can serve as a heuristic device, a placeholder for a variety of different readings that approach us. Rather than dismissing different practices as unwitting mistakes in judgement about the real world (where text always only represents substance), we could make use of the friction produced in the proximity of multiple ontologies, perhaps even know to read otherwise.

To think the multiplicity of ontologies, we do not have to essentialise some segregated spaces of stubborn difference. Recalling my very early life, I now think that it happened at the junction of two ontologies of reading. When I was four years old, Nura, my grandmother, received from a hodža (a Muslim priest), in our small, northern Bosnian town of Brčko, a piece of paper with what seemed like Arabic letters written across it. As neither of us could read Arabic, it was accepted as Qur'anic text. Nura was advised to soak it into a glass of water and drink the extraordinary liquid for a few days, after which she would feel better. Later on, I playfully reenacted this experience for others, offering my expert medical advice in a glass of water when needed. I cannot remember if the inscription helped Nura's medical problem at the time, but she certainly continued acquiring them, sometimes depositing little bundles in her pillowcase. ${ }^{1}$ Although my grandparents became the sudden communist epitomes of the Yugoslav state's working classes, my parents, equally suddenly, had an opportunity for a socialist formal education. Whilst both of my grandmothers were made to leave primary schooling after the fourth grade and focus on domestic work, four out of seven of their children attained PhD degrees. My parents' shifting habitats were always full of books, worn-out and underlined, and pages of their own manuscripts edited in red or blue ink and annotated along the margins. This too featured in my childhood games. I experimented with their analytical approach to text, secretly adding to their pages proofreading symbols - as if divining - the provenance of which puzzled them for some time. Neither my grandmother's nor my parents' approach to text were particularly odd to me, precisely because everything was odd as I worlded. ${ }^{2}$ Later on, the notion of critical reading - an attendance to disembodied text-became predominant. I had been gradually-although 
not fully-deontologised. Even if these two kinds of reading increasingly came to inhabit the opposite sides of the demarcation between private and public in Yugoslavia, a neophyte reader like me inevitably traversed these spaces. Despite my possibility to understand Nura's action, the hegemony of text as representation has had lasting consequences: I wonder if I'll ever again be able to drink text the way she taught me.

I offer this autobiographical note partly as a critique of the idea that 'other' ontologies stand in contrast to some 'Western' or 'Euro-American' conceptual constellation. We may think that reading in divination-for example the reading of a palm or a coffee cup - is an exercise in figurative language, an allusion to the interpretation of a written text, but it seems that the case may be quite the opposite. The complex etymology of the English verb 'read' suggests a multiplicity of meanings beyond the scanning or studying of written and printed text. In a variety of Germanic cognates whence it sprung, it carries the meanings of 'to advise', 'to deliberate', 'to help', 'to guess', 'to think', 'to arrange', 'to undertake' and so on (OED 2020). The Middle Low German rāden, for example, contains the senses of 'to rule', 'to predict', 'to relate'. Further back, tracing the Indo-European connections, reading is probably related to Old Church Slavonic raditi, 'to attend to, to take care of (a thing)' and Sanskrit rādh-, 'to succeed, accomplish' (ibid.). These origins of reading do not suggest some primacy of the written text. Rather, they connote a certain efficacious engagement with the world - a possibility to actualise something with direct relevance for the future. Etymologies, though not destinies, point to the ways in which others have dealt (and, sometimes, continue to deal) with meaning. Nura's drinking of text is reading in the sense of accomplishment, undertaking, relation and care for something. It is reading as worlding.

\section{Reading Otherwise: From Nura to Sudan}

Nura's rituals belong to much wider reading groups. The practices of imbibing of sacred texts are widespread, particularly in various Muslim contexts. They may have something to do with the audible histories of the Qur'an and the construction of personal relationships with God's message and the last messenger. The word Qur' an translates as 'Recitation'. During the Prophet's life, and for a few decades afterwards (at least until the third Caliph, 'Uthmān), it did not take a written form as the textus receptus 
(Graham 1984: 361-2). Recitation in classical Arabic, usually euphonic, continues to be a pervasive way of accessing its meaning around the world, even when the reciters cannot actually speak Modern Standard Arabic. Since the Qur'an is, more often than not, internalised as an aural entity, it requires a kind of 'bodily reception' similar to ingestion. The Qur' an's relation to the listener (or imbiber) starts from intimacy, not in critical distance. Each of its parts is taken as a microcosm of its entire truth, even when it may not be completely comprehensible as such. Otherwise, one would need to stop, translate, analyse and interpret, and then attempt understanding.

As Saba Mahmood (2009) has argued, the bafflement with apparent personal injury that some Muslims have expressed following the publication of the Danish cartoons depicting prophet Muhammad in the 2000s primarily points to the misunderstanding of different reading practices. The problem, she noted, is that some aspects of secular modernity, as well as Saussurean linguistics, rest upon what she called the 'Protestant semiotic ideology' and its 'distinction between object and subject, between substance and meaning, signifiers and signified, form and essence' (Mahmood 2009: 72). Insisting on these constellations as the paramount form of relation to the world constructs other reading practices as incorrect. ${ }^{3}$ The Prophet, as Mahmood suggested, is often not simply a figure of authority, but one carefully emulated: 'These mimetic ways of realizing the Prophet's behavior are lived not as commandments but as virtues where one wants to ingest, as it were, the Prophet's persona into oneself' (Mahmood 2009: 75).

Yet, the cases of bibliophagy and graphophagy are not simply about mimesis, as Finbarr Barry Flood has noted; they may 'point to a desire to collapse the distinction between emulator and emulated' (2014: 463). Although the visual depictions of the Prophet, particularly his face, are rare, a number of practices emerged early on that understood his physical body as one with his persona. Even during his life, the Prophet is said to have offered, from his mouth, his ablution water and the juice of the dates he chewed and mixed with his saliva, but also his sweat, for others to ingest or put over their bodies as a blessing. ${ }^{4}$ After the Prophet's death, his mantle, footprints, nail trimmings, hair, sweat and saliva were treasured (Flood 2014: 469). ${ }^{5}$ Many of these relics are kept on display in the TopkapiPalace in Istanbul today, which is where I first came across them. I was mystified by the apparent veneration of a single hair from the Prophet's beard, and it did not even occur to me at the time that kindred practices might have been 
transpiring around me my whole life, that the relic was at least comparable to the act of kissing the household copy of the Qur'an and touching it with one's forehead after reading, or carefully placing it on the highest position on the bookshelf.

As soon as I started writing this article, imbibing-as-reading appeared to be a phenomenon well attested in literature (for example, Ware 2014, El-Tom 1985, Nieber 2017, Flood 2014, Tsakos 2019, Lambek 1990), although, for the most part, with reference to the African continent. Several colleagues directed my attention to similar practices around the world. For example, drinking water into which Qur'anic text on a piece of paper is dipped is also to be found in Azerbaijan, and Kazakh pilgrims still break off stone fragments of the tomb of the Sufi sheikh Zeynulla Rasulev in Troitsk, which are then pulverised, dissolved in water and imbibed (Di Puppo and Schmoller 2019: 144). ${ }^{6}$ Jesko Schmoller kindly shared with me a photograph from his archives of a text written with saffron ink and sold for medicinal consumption in a store selling religious products in Troitsk.

It is important to note, however, that ingesting or imbibing text is neither equally shared by all Muslims nor endemic to Muslim traditions (Flood 2014: 461). ${ }^{7}$ Finbarr Barry Flood argues that not only is there ample evidence for such practices before Christ in the eastern Mediterranean, but certainly also as part of Christian devotion from its early days to the present (Flood 2014: 462). There is a wide plethora of similar practices that seem to translate the meaning of a symbolic place through ingestion. Inscribed earthen tablets are carried away and sometimes consumed by Shî̀ pilgrims to the Karbala and Najaf shrines (ibid.: 468). A couple of decades ago, I received as gift from a pilgrim one of these small Karbala tablets, made from dust on which the Prophet's grandson, Husayn, is said to have been killed in 680. It was used as a base for the forehead during prayer. Similar tablets were made in Medina, the soil of which the Prophet is said to have mixed with his own saliva as medicine for others' wounds (Flood 2014: 468-9).

Hanna Nieber (2017) noted that both Muslims and Christians in Zanzibar imbibe kombe, a pink liquid produced by dissolving Qur'anic text, written with saffron ink on paper or ceramic plates, in water. Its medicinal effects are generally understood to work beyond religious boundaries (ibid.). The plate needs to be plain, without any decoration, and the water neutral, 
although there is some preference for that from the Zamzam Well or untouched rainwater (Nieber 2017: 458-9). This might imply that other meanings and forces - not all of them good-may be 'properties' of the same material, and thus transferable. So, it is not just Qur'anic text that has such powers. The plainness of the plate could also suggest that the articulation of Qur'an is perfect, and that its completeness would be marred by any embellishment. Nieber's interlocutors have had different choices as to the verses of the Qur'an to be inscribed: some were selected at random, others purposefully to address specific ailments, and yet others through divine inspiration (Nieber 2017: 459-60). It was understood that any part of the Qur'an can provide healing (ibid.). ${ }^{8}$

A very similar practice of drinking Qur'anic text rinsed from a white plate exists among the Malagasy-speaking villagers of Mayotte (Comoro Islands, East Africa), who use it for various medicinal purposes, including against the 'evil eye' (Lambek 1990: 27). Drinking the water into which Qur'anic verses written on wooden tablets had been washed is a widespread practice across West Africa as well, where it is closely associated with Qur'anic schools, as way of embodying divine knowledge and attaining spiritual powers (Ware 2014: 57-64). The water retains the capacities transferred to it through the ritual of erasure, so it needs to be discarded in a safe place like woodland or underneath a Qur' anic school (Ware 2014: 59-60). ${ }^{9}$ Countering the colonial interpretation of the act as the 'Africanisation' of Islam, or at least a practice that surfaces along the peripheries of religion, Ware suggests that imbibing and ingestion of text are probably as old as Islam (ibid.: 58-9). Similar Muslim and non-Muslim practices have certainly existed outside of the African continent. For example, St Bede (c. 673-735) mentioned that scrapings from books in Ireland were mixed with water to treat snakebite (Flood 2014: 480). There are several indications of bibliophagy in the Bible. Consider the following verses:

And I went unto the angel, and said unto him, Give me the little book. And he said unto me, Take it, and eat it up; and it shall make thy belly bitter, but it shall be in thy mouth sweet as honey. (Revelation 10:9 King James Version [KJV])

Moreover he said unto me, Son of man, eat that thou findest; eat this roll, and go speak unto the house of Israel.

So I opened my mouth, and he caused me to eat that roll. 
And he said unto me, Son of man, cause thy belly to eat, and fill thy bowels with this roll that I give thee. Then did I eat it; and it was in my mouth as honey for sweetness.

And he said unto me, Son of man, go, get thee unto the house of Israel, and speak with my words unto them. (Ezekiel 3:1-4 KJV)

Thy words were found, and I did eat them; and thy word was unto me the joy and rejoicing of mine heart: for I am called by thy name, O LORD God of hosts. (Jeremiah: 15:16 KJV).

Despite the very literal description of ingestion - 'filling of the bowels' - these verses are usually interpreted as figurative. Various exegetes have taken the act as an intellectual absorption: eating 'as if', as 'symbolic', 'due reading', 'diligent perusal', 'careful reception' or 'identification with' text. ${ }^{10}$ The meaning holds the text at bay, requiring an exercise in substance dualism. Nevertheless, the benefits of bibliophagy may have been understood quite literally.

Considering a number of photographs taken in West Sudan, especially Kordofan, by Enikoü Nagy in the 2000s, Alexandros Tsakos noticed that Qur'anic verses were washed off from wooden tablets or from the interior of bowls and imbibed, but that they may have also been written on bits of paper to be ingested or burnt and inhaled (2019: 977-99). Among the Berti of the northern Darfur Province, a faki (graduate of a Qur'anic school who memorises the Qur'an by heart) would write Qur'anic verses 'on both sides of a wooden slate (lōh) using a pen made of a sharpened millet stalk and ink (dawai i) made of a fermented paste of soot and gum arabic' (El-Tom 1985: 415). Such text was again washed off with water and drunk by the clients once or twice a year (El-Tom 1985: 416). Noting that the water is called mihāi (from yamha, 'to erase'), Abdullahi Osman El-Tom adopted the previous translation of the practice as 'erasure' (El-Tom 1985: 415). This translation, it would seem, relates to one segment of the relationship between the text, the water, and the body. Yet, as the Zanzibari case shows, the text is not destroyed, but is rather transformed and 'circulates' (Nieber 2017: 461, 464). Erased from the tablets, it becomes one with the water; once drunk it becomes one with the body. 'Erasure' could then also refer to the preparation of oneself as a 'clean slate' for the transfer of knowledge actualised by water (cf. notes 12 and 13). 


\section{My Grandmother Drank the Qur'an}

\section{Amalgamations: A Bosnian Reading}

In Bosnia, zapis (lit. 'inscription'), like the one imbibed by my grandmother, refers to a variety of sacred notes and magical formulas - usually Qur'anic verses in Arabic on a piece of paper-provided by the person equipped with divine knowledge (such as the local hodža, Muslim priest/teacher) to someone looking for protection from spirits (džini), a curse/the evil eye (urok) or dark sorcery (sihir), but also to bring good luck and address any physical and psychological afflictions (see Bringa 1995: 178-182, 216-17).

Such texts may also heal the landscape. The so-called 'field inscriptions' (poljski zapisi), written for the protection of agricultural land, have been well documented. In fact, some of the oldest known Bosnian zapisi were curious syncretic formulas discovered by chance. In 1905, the villagers of Ječmište in Eastern Bosnia dug up a pine trunk and found in it a paper scroll carefully covered in wax and wrapped in cloth (Truhelka 1906a, Hadžijahic 1974). Likely from the sixteenth century, it was inscribed in medieval Bosnian Cyrillic, with segments in Latin script. ${ }^{11}$ It was written on behalf of 29 mentioned Muslim inhabitants of the 'Kunovo area', who sought protection from the devil, thunder, cold, hail and dry wind. The text records twenty different names for the devil. These various afflictions were 'repelled' with a careful list of figures usually invoked in Christian rites, including Jesus, Mary, the patriarchs, the saints, and the archangels. Similar inscriptions in Bosnia were usually found on lead tablets, like the one reported at the beginning of the twentieth century in the Herald of the National Museum, which, again in Bosnian Cyrillic, called upon the Christ's resurrection, the evangelists, the holy fathers and the martyrs, as well as the 'four rivers encompassing the earth' (Truhelka 1906b, Hadžijahić 1974).

These zapisi show not only the early amalgamation of Islam and Christianity in Bosnian folk textual traditions, but also that humans and other-than-humans were entwined in reading practices. Like humans, the earth could 'swallow' textual knowledge to realise particular futures. It is quite interesting that the Kunovo zapis includes repeated references to the Logos doctrine, by way of quotes from John 1:14 (see Hadžijahić 1974). The Word, 'made flesh' and 'residing in us', offers itself to elaboration in the rituals of corporeal ingestion (by land or humans) such as the ones found in Bosnia. 
Leopold Glück, an Austrian physician working in Sarajevo at the turn of the twentieth century, noticed that 'the Bosnian and Herzegovinian man believes in inscriptions [zapis], even without knowledge of that which is inscribed on it, only because he thinks it is sacred and thus must help' (Glik 1890a: 47). He mentioned a variety of Muslim, Jewish, Catholic and Orthodox Christian zapisi in Bosnia. The Muslim ones, he thought to be more complex and astrologically informed than the others. To accept a zapis, he noted, one must first perform ablution and utter prayer (Glik 1890a: 50). ${ }^{12}$ Such notes were always directed to specific ailments. The 'headache zapis' could be written on a crust of hot bread (somun) to be eaten, or on a willow leaf to be placed in a glass of water and imbibed (Glik 1890a: 52). He also reported on zapisi he had seen written on gold or silver plates, eggshells or butter, as well as ones that needed to be penned in colourful ink or sacrificial animal blood (Glik 1890a: 53). Similarly, the nineteenthand twentieth-century North African edible magical inscriptions could be made not only on paper but also on eggshells, onion skins and wheat grains (Flood 2014: 481).

In another report on Bosnian customs during childbirth, Glück added to the list of folk remedies the cross-religious practices of icon visitation, spells and inscriptions, and help from rabbis and hodže (Glik 1890b). To this day, Bosnian Catholics and Orthodox Christians frequently acquire hodža's inscriptions just like Muslims (Bringa 1995: 182). They may be worn as amulets, close to one's body, but not left in polluted spaces such as the toilet, if not previously protected by oil (Bringa 1995: 216-7). It may also be placed in water and imbibed. Since the potency of zapis transfers through substances like water onto the body, it may also attract other forces, so a hydrophobic matter such as oil needs to lock it away. This is similar to the mentioned Zanzibari rationale for 'plain' kombe plates and water.

Certain 'flowing' substances seem to set in motion such transference between bodies better than others (see Carsten 1995, 2011). Whether this is blood or blood-soaked earth (as in the case of Karbala), saliva, water, semen, fumes or foodstuffs, their properties of flow and circulation have been widely understood as useful to carry meaning across various boundaries. The power of water to transmit substance is pervasive in contemporary Bosnia, and almost exclusively related to women-led practices. One of the most ubiquitous rituals is omaha on the St George's morning, when young women go to water rapids or water mills and bathe 
nude in their droplets (see HadžiMuhamedović 2018: 192-3). ${ }^{13}$ Another fertility ritual that women engage in is the drinking of or ablution with water from the walls of caves. I have recorded one such moment in Djevojačka pećina (lit. 'Maiden's Cave') in central Bosnia, where women touched the cave walls and then wiped their faces. The cave drippings were also packaged and sold to pilgrims for later medicinal consumption. Water as a diffuser of powerful meaning is, of course, more widely utilised. Transferring text onto the body by way of holy water is widely present in Christian practice. Roman Catholic holy water is known to have been used by Bosnian Muslims as a remedy for a variety of worries (see Bringa 1995: 214). Likewise, the holy Zamzam water from Mecca used to be poured on Ibrahim's footprints in stone and imbibed (Flood 2014: 471).

Another Bosnian form of divination through water-salivanje strave (lit. 'pouring out of horrors') - is again performed by women. A lump of lead is heated to melting point and poured into a container of water above the head of the patient who sits still covered by a sheet (see ibid.: 215-16, Jašarević 2012: 918). ${ }^{14}$ Qur'anic verses are whispered into both the water and the lead (Jašarević 2012: 928). The shapes of the lead are interpreted to uncover the cause of the ailment, and the process is repeated until they emerge 'smooth and shiny' (Jašarević 2012: 915, 919). Some of the treated water is later ingested, and the lead is melted and reused in other séances (Jašarević 2012: 922, 928). Furthermore, as Jašarević has noted, the 'treatment is complete only when the patient has bathed at home from head to toe with the bottled "fears water," reciting wishes for recovery as the strava woman has instructed' (Jašarević 2012: 929). In other words, water 'accepts' the Qur'an and acts as a knowledge conductor. To expel the 'horrors', the patient was supposed to recite certain formulas during the ritual. ${ }^{15}$ For example, they could say: 'Adam's head ached; Adam passed it onto Eve; Eve passed it onto the snake; the snake passed it onto the apple; the apple passed it onto the sun; the sun passed it onto the sea; the sea passed it onto the wind, and the wind dispersed it'. ${ }^{16}$ This transubstantiation of an ailment is similar to the one involving water and lead in salivanje strave. Likewise, the beneficial properties of texts, trees or saint's tombs could be 'passed on' through water.

The power of Qur'anic water healing is also strong enough to cross religious boundaries, whether in Bosnia, Zanzibar or elsewhere. As El-Tom notes for Darfur, the Qur'anic text provides both power and protection, 
and becomes particularly potent when learnt by heart (1985: 416). In terms of effectivity, he positions the drinking of Qur'anic text between full memorisation and amulets worn on the body, as the latter may be displaced (ibid.). Once admitted into the body (as sound-knowledge or liquid-knowledge), the text is then less prone to eviction; its meaning is fused with one's being, so that the synthesised text-body may become more efficacious.

\section{Towards Trust}

What would, in the end, be the value of thinking reading through the imbibing practices of text? One answer-reflected in the murky IndoEuropean precursors of the English word as accomplishment, care or relation-perhaps lies in their focus on efficacy and embodiment. The widespread acts of liquid reading reveal that in the resolute abstinence from imbibable (or edible, audible, and inhaled) knowledge, we may never actually relate to text, or at least not without the caveat of corporeal distance. A myriad of historical and contemporary readings lacking in such limitations inform us that for some the text/meaning binary has no purchase on the world.

Before drinking the Qur'an, the reader's body already has the potential to activate its knowledge, but nevertheless needs to be prepared to receive it with full confidence. Rather than the reader's analytical diagnostic of the text, this relation of trust suggests that the text itself is a diagnostic tool. For example, kombe only works if the person already possesses imani (belief/faith/trust) in their heart upon imbibing it (Nieber 2017: 464), and potable inscriptions in Bosnia require prayer and life of dedication. The possibility of trust turns the tables on conventional critical reading, articulating a new kind of critique as an always potential openness.

As I write this article, novel inter-corporeal borders continue to be assembled under the guise of a virus, the refugees, and the racialised other. The coronavirus has awakened the horrors of dangerous matter, leaping unbidden from body to body. In the cases of epidemics and other calamities, one sub-Saharan African tradition is for the community to ingest not just a couple of verses but the whole Qur'an (Flood 2014: 480-1). If imbibing-asreading bridges this dissociative trap - across the negation of the vitality of textual materiality in favour of its more valuable substance - we may need 
to employ it as didactic method for a world proliferating in partitions. As Jane Bennett has noted, 'the image of dead or thoroughly instrumentalized matter feeds human hubris and our earth-destroying fantasies of conquest and consumption' (2010: ix). Liquid readings encourage deep transfer between bodies - material bodies, bodies of knowledge, religions, of human and other-than-human beings-understood as highly permeable. And, particularly when their capacities are set in motion by flowing substances, such as water, which may dissolve text and push it over the boundaries of ossified domains.

I would like to close by returning to Nura. About the same time as the 'imbibing' episode (late 1980s), she received from a close friend this mysterious bedtime incantation, which we recited together, against her pillowcase:

Abesi vebesi, Sulejman pejgamber, muhri sizi tucun.

I came to know these words by heart, later wondering if they had been nothing more than the invention of some hodža looking to make a bit of money. But as I write this article, I recognise that Nura's incantation refers to Mühr-ü Süleyman, the powerful Seal of Prophet Solomon, the master of esoteric knowledge in Jewish, Christian and Muslim entwined traditions, who knew how to speak to the birds and commanded over the winds and the spirits (Qur'an 27:16; 34:12). ${ }^{17}$ Neither Nura nor I knew for certain whether the words were 'translatable' into some attested language. Instead, we engaged in an exercise of trust, receptively apprehending them by our bodies.

\section{Acknowledgements}

I would like to thank Vanja Hamzić, Amra Hadžimuhamedović, and Marija Grujić for their insightful comments on an earlier draft of this article. My thanks also go to Jesko Schmoller and Calvin Tiessen for providing me with helpful examples from their research, as well as to Ruth Jackson Ravenscroft, Simone Kotva and Laura McCormick Kilbride for inviting me into this wonderful conversation. All omissions and inaccuracies in this article are my own.

\section{Notes}

1. My interlocutors in Gacko (south-eastern Bosnia) told me about a similar practice of placing efficacious dust from old oaks, known as izijes, into their family's pillowcases. Sometimes, izijes achieved an increased libido in men. The pillowcase of Gacko's oak dust and Nura's magic inscriptions is a site of productive proximity. Its nocturnal touch 


\section{CounterText}

against the head makes the flow of matter-meaning particularly successful. I think of it as a form of bedtime reading.

2. This is not to suggest that my parents' approach to text was unambiguous. For example, a copy of the Qur'an would be taken into an apartment before we moved into it ourselves, and it would occupy the highest place above other books on a shelf.

3. Mahmood notes: 'It is this same vision that seems to inform the well-meaning pleas circulating in Europe today for Muslims to stop taking the Danish cartoons so seriously, to realize that the image (of Muhammad) can produce no real injury given that its true locus is in the interiority of the individual believer and not in the fickle world of material symbols and signs' (2009: 72-73).

4. See Sahih al-Bukhari (Vol. 1 Book 4 Hadith 187 and Vol. 5 Book 58 Hadith 248) and Sahih Muslim (Book 30, Hadith 5762).

5. Flood (2014: 469) also mentions how the powdered nail trimmings of the Prophet were placed in the mouth and the eyes of the first 'Umayyad caliph Mu'āwiya upon his death, whilst others (like Nūr al-Dīn b. Zengì) were buried with a hair of the Prophet placed on their tongue and each of their eyes.

6. For highlighting the Azerbaijani practice, thanks go to Calvin Tiessen, and to Jesko Schmoller for the examples from the Russian Urals. Reminiscent of the Kazakh practice, Bosnian Muslims take home chips of rock from the pilgrimage of Ajvatovica and pulverise them to spread over and fertilise the crops (see HadžiMuhamedović 2018: 48).

7. Flood (2014: 475) notes that early and medieval Muslim juridical texts offered different opinions on the acceptability and legality of such ingestion.

8. Nieber (2017: 467) notes that verse 17:82 from the Qur'an - 'We send down the Qur an as healing and mercy to those who believe' - is commonly inscribed for kombe, but with the second part usually omitted.

9. This is similar to Roman Catholic disposal of holy water.

10. See, for example, the various commentaries on Revelation 10:9 (Bible Hub 2020) and Tsakos (2019: 980).

11. The Kunovo inscription is primarily in old Bosnian Slavic, with segments in Latin language. Parts of the Latin language verses are written in Latin script and others in Bosnian Cyrillic. Hadžijahić (1974) presented a convincing argument of this inscription's connection to dualist teachings and the medieval Bosnian Church.

12. Similarly, ablution and a prayer are the central rituals of 'becoming' a Muslim.

13. I could not locate any etymological studies of the Bosnian noun omaha. However, in light of the practices of Qur' anic 'erasure', it may be interesting to explore the possible connections of Bosnian omaha - the ritual of springtime washing and renewal-with the Arabic verb محا (mahā), meaning 'to erase', particularly the passive present tense أمحى ( umhā), 'I am erased'.

14. Both Glück (1892) and Ugljen (1893) noted that the lead melted comes from shotgun shells, and Glück also mentioned that the lead fumes were supposed to be inhaled by the patient. Ugljen (1893: 69) on the other hand, adds that a woman could take the 


\section{My Grandmother Drank the Qur'an}

lead home in a glass of water and throw it over the house roof, catching it three times, with which she would then nurse and wash the cheeks of a 'scared' child. The used lead called salitak (lit. 'the pouring') would be taken to a crossroads, where the malady would be transferred onto the first passer-by to pick it up.

15. I have recently found out that my father Fehim has undergone the ritual of 'horror pouring' when he was a child. It was co-orchestrated by his mother (Nura, of this story) and grandmother (Safija, known as Bika). Upon reading a draft of this article, my mother Amra also remembered the atmosphere of the 'horror pouring' sessions, which were organised by a woman healer in her hometown of Stolac. In other words, alternative forms of reading have complicated, transgenerational life-histories, surfacing unexpectedly and against odds.

16. Reported by Glück, this incantation in Bosnian goes: 'Adama zaboljela glava; Adam predade Evi, Eva predade zmiji, zmija predade jabuci, jabuka predade suncu, sunce predade moru, more predade vjetru, a vjetar raznese' (1892: 72).

17. Rusmir Mahmutćehajić notes: 'Solomon's seal is found in Bosnian churches and mosques, which may puzzle the uninitiated for whom this symbol of perennial presence has come to be regarded as "Jewish." It is also common on Bosnian Muslim artefacts, like tombstones, manuscripts, inscriptions, furniture, and silver lockets or enamluks "worn close to the heart" (2015: 377, n. 1).

\section{References}

Bennett, Jane (2010), Vibrant Matter: A Political Ecology of Things. London: Duke University Press.

Bible Hub (2020), 'Revelation 10:9'. < https://biblehub.com/commentaries/ revelation/10-9.htm > accessed 7 July 2020.

Bringa, Tone (1995), Being Muslim the Bosnian Way: Identity and Community in a Central Bosnian Village. Princeton, NJ: Princeton University Press.

Carsten, Janet (1995), 'The Substance of Kinship and the Heat of the Hearth: Feeding, Personhood, and Relatedness among Malays in Pulau Langkawi'. American Ethnologist 22: $2,223-41$.

Carsten, Janet (2011), 'Substance and Relationality: Blood in Contexts Annual Review of Anthropology 40: 19-35.

Di Puppo, Lili and Jesko Schmoller (2019), 'The Revival of Sacred Sites in the Urals: The Local and Beyond'. Journal of Ethnology and Folkloristics 13(2): 143-145.

El-Tom, Abdullahi Osman (1985), 'Drinking the Koran: The Meaning of Koranic Verses in Berti Erasure'. Africa: Journal of the International African Institute 55(4): 414- 431.

Flood, Finbarr Barry (2014), 'Bodies and Becoming: Mimesis, Mediation and the Ingestion of the Sacred in Christianity and Islam', in Sally M. Promey (ed.), Sensational Religion: Sensory Cultures in Material Practice. New Haven: Yale University Press: 459-93.

Glik, Leopold (1890a), 'Hamajlije i zapisi u narodnjem ljekarstvu Bosne i Hercegovine' Glasnik Zemaljskog Muzeja. Sarajevo: Zemaljski muzej Bosne i Hercegovine: 45-55 < http://www.infobiro.ba/article/397953 > accessed 6 July 2020. 


\section{CounterText}

Glik, Leopold (1890b), 'Narodni običaji pri porođaju'. Glasnik Zemaljskog Muzeja. Sarajevo: Zemaljski muzej Bosne i Hercegovine: 283-92. http://www.infobiro.ba/ article/398693.

Glück, Leopold (1892), 'O stravi: prilog narodnom ljekarstvu Bosne i Hercegovine'. Glasnik Zemaljskog Muzeja. Sarajevo: Zemaljski muzej Bosne i Hercegovine: 70-72. Accessed on 6 July 2020 at http://www.infobiro.ba/article/407223.

Graham, William. A. (1984), 'The Earliest Meaning of 'Qur'àn'. Die Welt des Islams 23(1-4), 361-377.

Hadžijahić, Muhamed (1974), 'O jednom manje poznatom domaćem vrelu za proučavanje crkve bosanske', Prilozi Instituta za istoriju BiH 10: 2, 55-107.

HadžiMuhamedović, Safet (2018), Waiting for Elijah: Time and Encounter in a Bosnian Landscape. Oxford: Berghhan.

Henare, Amiria (2007), 'Taonga Mäori: Encompassing Rights and Property in New Zealand'. In A. Henare, M. Holbraad and S. Wastell (eds) Thinking Through Things: Theorising Artefacts Ethnographically. London: Routledge: 47-67.

Henare, Amiria, Martin Holbraad, and Sari Wastell (eds) (2007), Thinking Through Things: Theorising Artefacts Ethnographically. London: Routledge.

Holbraad, Martin (2007), 'The Power of Powder: Multiplicity and Motion in the Divinatory Cosmology of Cuban Ifá (or mana, again)', in Amiria Henare, Martin Holbraad, and Sam Wastell (eds) Thinking Through Things: Theorising Artefacts Ethnographically, London: Routledge: 189-225.

Jašarević, Larisa (2012), 'Pouring Out Postsocialist Fears: Practical Metaphysics of a Therapy at a Distance'. Comparative Studies in Society and History 54(4): $914-41$.

Lambek, Michael (1990), 'Certain Knowledge, Contestable Authority: Power and Practice on the Islamic Periphery'. American Ethnologist. 17(1): 23-40.

Mahmood, Saba (2009), 'Religious Reason and Secular Affect: An Incommensurable Divide?', in Talal Asad, Wendy, Brown, Judith Butler, and Saba Mahmood (eds), Is Critique Secular?: Blasphemy, Injury and Free Speech. UC Berkeley: Townsend Center for the Humanities: 64-100.

Mahmutćehajić, Rusmir (2015), The Praised and the Virgin. Leiden: Brill.

Nieber, Hanna (2017) “'They All Just Want to Get Healthy!” Drinking the Qur'an between Forming Religious and Medical Subjectivities in Zanzibar'. Journal of Material Culture 22(4): 453-75.

OED (2020), 'Read, v.' Oxford English Dictionary Online. Oxford: Oxford University Press. Accessed on 5 July at www.oed.com/view/Entry/158851.

Truhelka, Ćiro (1906a), 'Jedan zanimiv zapis, pisan bosančicom', Glasnik Zemaljskog Muzeja. Sarajevo: Zemaljski muzej Bosne i Hercegovine, pp. 439-354, < http://www. infobiro.ba/article/668496> accessed 6 July 2020.

Truhelka, Ćiro (1906b), 'Opet jedan zapis pisan bosančicom', Glasnik Zemaljskog Muzeja. Sarajevo: Zemaljski muzej Bosne i Hercegovine, pp. 540-41, < http://www.infobiro. ba/article/670538>, accessed 6 July 2020. 


\section{My Grandmother Drank the Qur'an}

Tsakos, Alexandros (2019) 'Materiality and Physicality of Medieval Manuscripts from Christian Nubia'. Cahiers d'études africaines 236(4): 967-92.

Ugljen, Sadik (1893), 'Olovo kao narodni lijek'. Glasnik Zemaljskog Muzeja. Sarajevo: Zemaljski muzej Bosne i Hercegovine: 168-170. Accessed on 6 July 2020 at http://www.infobiro.ba/article/416209.

Ware, Rudolph T. III (2014), The Walking Qur'an: Islamic Education, Embodied Knowledge, and History in West Africa. Chapel Hill, NC: The University of North Carolina Press. 